Article

\title{
Preparation of Calcium Stannate from Lead Refining Dross by Roast-Leach-Precipitation Process
}

\author{
Dixiu Wu ${ }^{1}$, Junwei Han ${ }^{1,2, *}$, Wei Liu ${ }^{1}$, Fen Jiao ${ }^{1}$ and Wenqing Qin ${ }^{1,2}$ \\ 1 School of Minerals Processing and Bioengineering, Central South University, Changsha 410083, China; \\ wdx6260@163.com (D.W.); liuweipp1@126.com (W.L.); jfen0601@126.com (F.J.); \\ qinwenqing369@126.com (W.Q.) \\ 2 Key Laboratory of Hunan Province for Clean and Efficient Utilization of Strategic Calcium-containing \\ Mineral Resources, Central South University, Changsha 410083, China \\ * Correspondence: hanjunwei@csu.edu.cn; Tel.: +86-13875815330
}

Received: 22 March 2019; Accepted: 7 May 2019; Published: 9 May 2019

\begin{abstract}
Lead refining dross containing plenty of tin and other heavy metals, such as lead and antimony, is considered a hazardous waste generated in large quantities in lead smelter plants. In this study, calcium stannate was synthesized from lead refining dross using sodium carbonate roasting and alkaline leaching followed by precipitation with $\mathrm{CaO}$. The effect of roasting and leaching parameters on the extraction efficiency of tin was investigated. The leaching efficiency of tin reached $94 \%$ under the optimized conditions: roasting with $60 \% \mathrm{Na}_{2} \mathrm{CO}_{3}$ at $1000{ }^{\circ} \mathrm{C}$ for $45 \mathrm{~min}$, and leaching using $2 \mathrm{~mol} / \mathrm{L} \mathrm{NaOH}$ solution for $90 \mathrm{~min}$ at $85^{\circ} \mathrm{C}$ and $8 \mathrm{~cm}^{3} / \mathrm{g}$ liquid/solid ratio. Furthermore, more than $99 \%$ of tin in the leaching solution was precipitated using CaO. Finally, XRD, SEM, and ICP-OES analyses indicated that the final $\mathrm{CaSnO}_{3}$ product had a purity of $95.75 \%$ and its average grain size was smaller than $5 \mu \mathrm{m}$. The results indicated that the developed method is feasible to produce calcium stannate from lead refining dross.
\end{abstract}

Keywords: alkaline leaching; secondary resources; hazardous waste reduction; smelting wastes; sodium roasting

\section{Introduction}

Lead, as one of the most common metals, has been widely applied in various fields, such as lead-acid batteries, protection from $\mathrm{X}$-ray and radioactive radiation, chemical anticorrosion, and solder [1-5]. It is primarily produced from lead sulfide concentrates through a sintering roasting-blast furnace smelting-refining process. The crude lead produced by blast furnace smelting requires a refining process to remove various impurities for obtaining refined lead (purity $>99 \%$ ) [6-9]. In general, tin is the main impurity in crude lead from which it is usually separated into the lead refining dross stream following oxidation since it has a stronger affinity for oxygen than lead [10-12]. As a result, considerable quantities of lead refining dross containing tin are produced annually [13-15] containing heavy metals, such as $\mathrm{Sn}, \mathrm{Sb}$, and As, which occur rarely as sulfides but mainly as oxides and oxidized compounds that are generally more soluble in the environment. Hence, the accumulation of lead refining dross not only takes up a mass of land, but also causes a potential environmental risk and a waste of valuable metals [16-22] such as tin which is a scarce metal. According to the International Tin Research Institute (ITRI), the reserve of economically recoverable tin was only $2.2 \mathrm{Mts}$ in 2016, which would merely meet the current global tin demand for approximately eight years [23,24]. It is therefore urgent to develop an economical and eco-friendly technology to recover tin from tin secondary resources for alleviating the financial burdens and environmental degradation. 
In the past decades, a large number of studies have been carried out for recovering tin from tin secondary resources including tin anode slime, tin-bearing alloys, electric-wastes, and tin-bearing slags. Various volatilization, selective leaching, alkaline fusion, and roasting-leaching processes are applied to recover tin from these tin secondary resources depending on the differences of phase composition and tin content [25-27]. Yang et al. [28] reported that a vacuum distillation process was conducted for recovering metals from waste Sn-based alloys at a distillation temperature of $900-1100{ }^{\circ} \mathrm{C}$ under a chamber pressure of 20-50 Pa. The recovery of tin was higher than $99 \mathrm{wt} \%$, and the content of impurities in the metallic tin was no more than $0.05 \mathrm{wt} \%$. Han et al. [29] proposed an alkaline pressure oxidative leaching process to pretreat tin anode slime. The extraction efficiency of tin reached $92 \%$ under the following conditions: leaching using $2.5 \mathrm{~mol} / \mathrm{L} \mathrm{NaOH}$ solution at $130{ }^{\circ} \mathrm{C}$ under $1 \mathrm{MPa}$ oxygen partial pressure. At the same time, antimony, bismuth, and silver hardly dissolved into the $\mathrm{NaOH}$ solution and were enriched in the residue. Kim et al. [30] reported that tin could be successfully leached from $\mathrm{Pb}$-free solder with $\mathrm{SnCl}_{4}$ and $\mathrm{HCl}$ solution at $50-70{ }^{\circ} \mathrm{C}$. Guo et al. [31,32] employed an alkali fusion-leaching-separation process to recycle tin from the copper anode slime and waste printed circuit boards (PCBs). The results indicated that the leaching rate of tin from the copper anode slime and waste PCBs reached $86 \%$ and $91.08 \%$, respectively. It is no doubt that these technologies developed have made some significant achievements, but they also have some drawbacks such as high energy consumption, severe equipment corrosion, and the emissions of $\mathrm{Cl}_{2}$. Furthermore, there are few studies on recycling of tin from lead refining dross, in which tin is mainly in the form of stannic oxide $\left(\mathrm{SnO}_{2}\right)$ that has a stable tetrahedral structure [33]. $\mathrm{SnO}_{2}$ is insoluble in mild acid or alkali solutions, and therefore, it is challenging to recover tin from lead refining dross by direct acid or alkaline leaching.

In the present study, the preparation of calcium stannate $\left(\mathrm{CaSnO}_{3}\right)$ from lead refining dross through sodium carbonate roasting, alkaline leaching, and precipitation with $\mathrm{CaO}$ was proposed for the first time. The objective of roasting is to convert the $\mathrm{SnO}_{2}$ contained in lead refining dross into sodium stannate, which is helpful for the selective extraction of tin in the subsequent alkaline leaching process. The effects of roasting conditions $\left(\mathrm{Na}_{2} \mathrm{CO}_{3}\right.$ addition, roasting temperature, and time) and leaching parameters $(\mathrm{NaOH}$ concentration, liquid/solid ratio, leaching temperature, and time) on the extraction efficiency of tin were systematically investigated. Meanwhile, phase transformations during the roasting process were revealed by $X$-ray diffraction (XRD) and scanning electron microscopy coupled with energy dispersive spectrometry (SEM-EDS) analyses. The final product obtained was characterized in detail by thermo-gravimetric and differential thermal analysis (TG-DTA), XRD, and SEM-EDS analysis.

\section{Materials and Methods}

\subsection{Materials}

The lead refining dross used in this study was collected from a lead pyrometallurgical plant in Jiangsu province, China. The main chemical composition of the lead refining dross is presented in Table 1. The results showed that the sample contained $54.20 \% \mathrm{Sn}, 8.92 \% \mathrm{Sb}$, and $6.45 \% \mathrm{~Pb}$, indicating that tin was the most valuable metal in dross. The main phases of $\mathrm{Sn}, \mathrm{Sb}$, and $\mathrm{Pb}$ in dross are shown in Tables 2-4, respectively. The results indicated that the tin contained in the dross was mainly in the form of $\mathrm{SnO}_{2}$, which has been confirmed by XRD analysis (Figure 1). The SEM-EDS analysis results of the dross are also presented in Figure 1. The results revealed that the lead refining dross was composed of mainly $\mathrm{SnO}_{2}$, some $\mathrm{Sb}$ and $\mathrm{Pb}$, and minor $\mathrm{Fe}$, which was in accordance with the results given in Tables 1 and 2.

Table 1. Main chemical composition of lead refining dross (wt \%).

\begin{tabular}{cccccccc}
\hline Elements & Sn & Sb & Pb & Fe & Cu & S & Si \\
\hline Contents & 54.20 & 8.92 & 6.45 & 0.51 & 0.04 & 0.135 & 0.046 \\
\hline
\end{tabular}


Table 2. Tin phase composition of the lead refining dross.

\begin{tabular}{cccccc}
\hline $\begin{array}{c}\text { Phase } \\
\text { Composition }\end{array}$ & $\mathrm{SnO}_{\mathbf{2}}$ & Sn & Silicate & $\mathbf{S n C l}_{\mathbf{2}}$ & Total \\
\hline Sn content $(\mathrm{wt} \%)$ & 53.90 & 0.10 & 0.11 & 0.09 & 54.20 \\
Percentage $(\%)$ & 99.44 & 0.19 & 0.20 & 0.17 & 100.00 \\
\hline
\end{tabular}

Table 3. Antimony phase composition of the lead refining dross.

\begin{tabular}{cccccc}
\hline $\begin{array}{c}\text { Phase } \\
\text { Composition }\end{array}$ & $\mathbf{S b}_{\mathbf{2}} \mathbf{O}_{\mathbf{3}}$ & Antimonate & $\mathbf{S b}$ & $\mathbf{S b}_{\mathbf{2}} \mathbf{S}_{\mathbf{3}}$ & Total \\
\hline Sb content $(\mathrm{wt} \%)$ & 6.06 & 2.59 & 0.25 & 0.024 & 8.92 \\
Percentage (\%) & 67.94 & 29.06 & 2.80 & 0.20 & 100 \\
\hline
\end{tabular}

Table 4. Lead phase composition of the lead refining dross.

\begin{tabular}{cccccc}
\hline $\begin{array}{c}\text { Phase } \\
\text { Composition }\end{array}$ & $\mathbf{P b}$ & PbO & PbS & Silicate & Total \\
\hline Pb content $($ wt $\%)$ & 1.44 & 2.09 & 2.48 & 0.44 & 6.45 \\
Percentage $(\%)$ & 22.33 & 32.40 & 38.45 & 6.82 & 100 \\
\hline
\end{tabular}
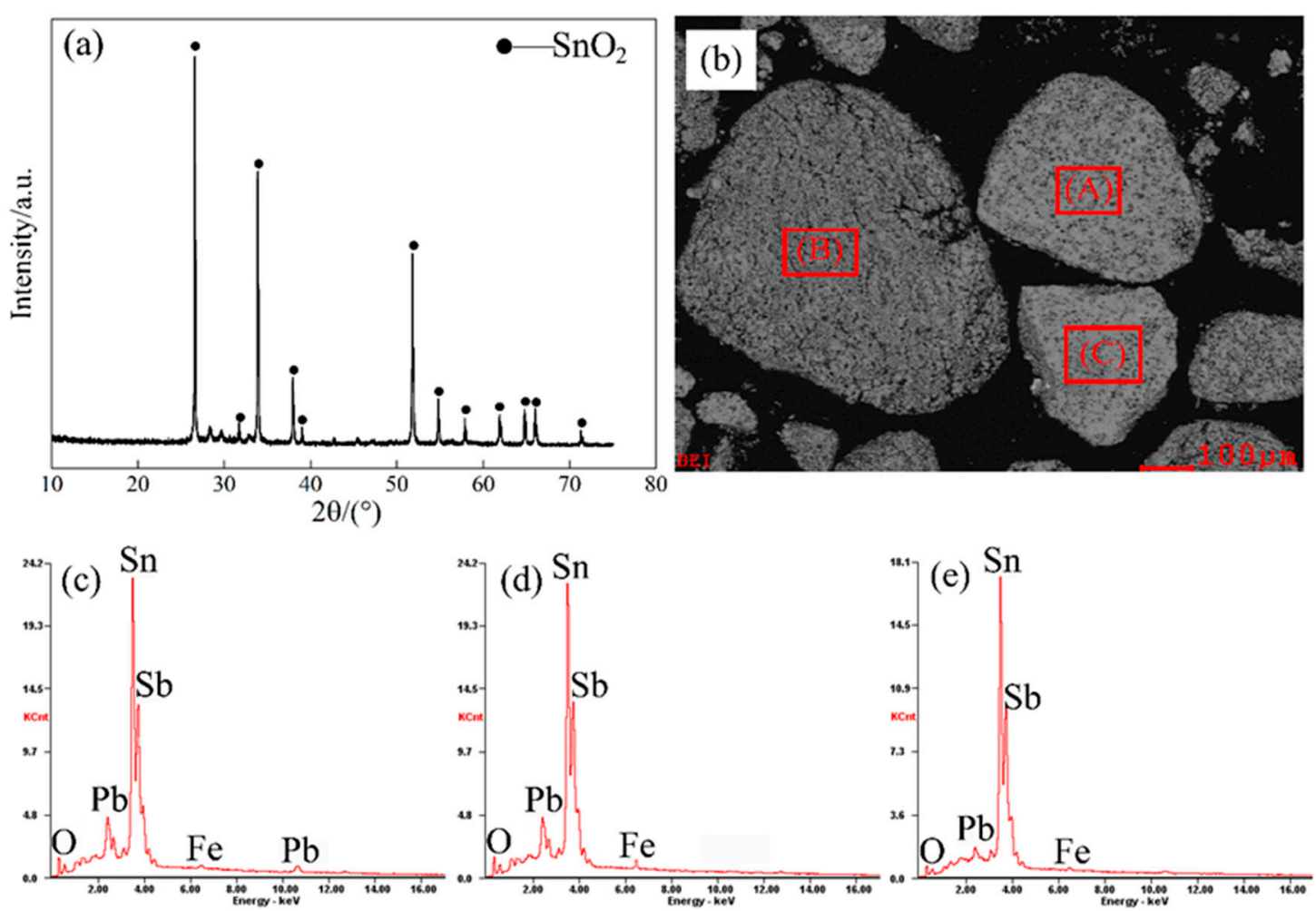

Figure 1. XRD pattern (a) and SEM image (b) of lead refining dross with energy dispersive spectrometry (EDS) spectra at points A (c), B (d), and C (e).

In addition, sodium carbonate $\left(\mathrm{Na}_{2} \mathrm{CO}_{3}\right)$ was used as an additive for sodium roasting. Sodium hydroxide $(\mathrm{NaOH})$ was used as the leaching agent for the leaching process. Sodium sulfide $\left(\mathrm{Na}_{2} \mathrm{~S}\right)$ was added to the leaching solution at the leachate purification stage to remove lead ions as lead sulfides. Calcium oxide $(\mathrm{CaO})$ was used to precipitate tin from the purified solution. All of these agents were of analytical grade and provided by Sinopharm Chemical Reagent Co., Ltd. (Beijing, China). 


\subsection{Methods}

The entire treatment scheme investigated for the production of calcium stannate from lead refining dross is given in Figure 2. The samples were first ground to $-74 \mu \mathrm{m}$, dried in a vacuum oven, and stored for subsequent experiments. For each test, $10 \mathrm{~g}$ of lead refining dross was thoroughly mixed with a certain amount of $\mathrm{Na}_{2} \mathrm{CO}_{3}$ using a mortar and pestle. The prepared mixture was put into a $50 \mathrm{~mL}$ porcelain crucible which was then placed into the muffle furnace for roasting. The samples were heated at a rate of $30^{\circ} \mathrm{C} / \mathrm{min}$ to a required temperature and roasted at this temperature for a specific time. When roasting was finished, the samples were taken out after cooling to below $100^{\circ} \mathrm{C}$. Finally, the roasted samples were weighed, ground and sieved to $-74 \mu \mathrm{m}$ for analysis and leaching tests.

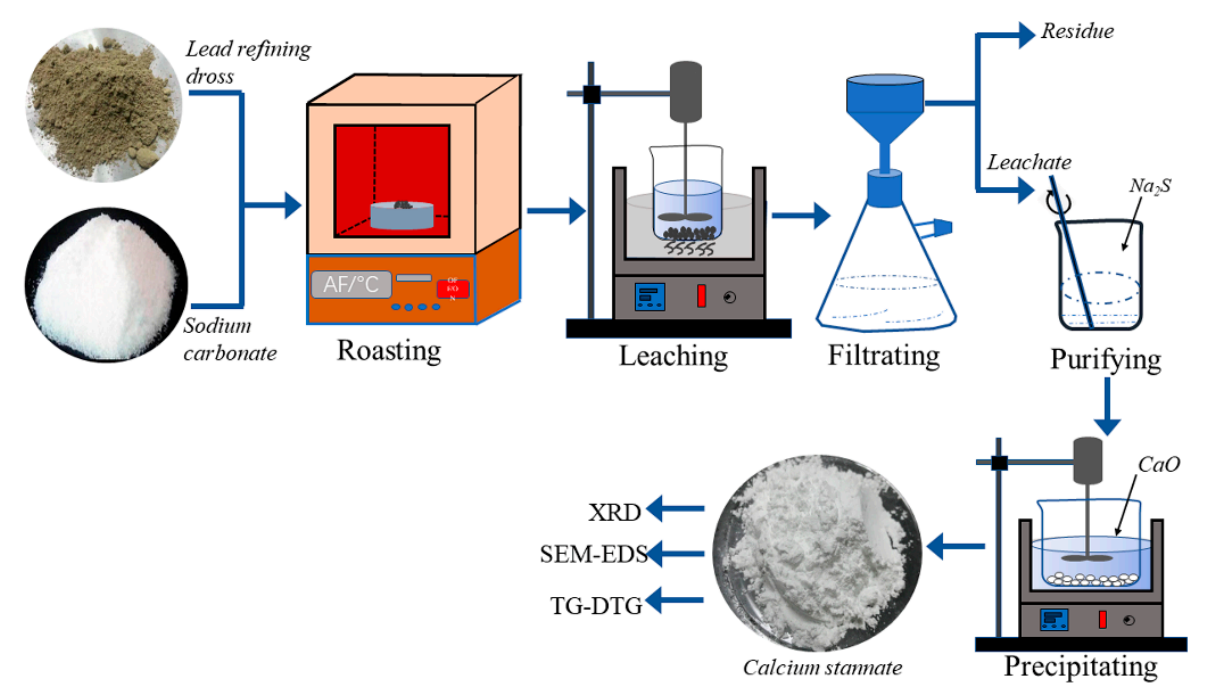

Figure 2. Flowsheet of the experimental process.

The leaching experiments were performed in a glass beaker of $500 \mathrm{~mL}$ equipped with a mechanical stirrer and placed in a thermostatic water bath. Prior to leaching, a $\mathrm{NaOH}$ solution was prepared according to scheduled concentrations and liquid/solid ratio, then placed into a beaker and heated at a particular temperature and stirred at $300 \mathrm{rpm}$. When the required temperature was reached, $10 \mathrm{~g}$ of the roasted sample was put into the beaker. When leaching was finished, the leaching residue was separated from the leachate by filtration. The filtrate was collected for the subsequent precipitation experiments, and the residue was dried, weighed, and analyzed by ICP-OES for tin content. The leaching efficiency of tin $(\eta)$ was calculated as:

$$
\eta=\frac{\alpha \cdot m_{0}-\beta \cdot m_{1}}{\alpha \cdot m_{0}} \times 100 \%
$$

where $\alpha$ and $\beta$ represent tin content in the samples before and after leaching, respectively (\%); $m_{0}$ and $m_{1}$ are the mass of the samples before and after leaching, respectively (g).

After a purification process with the addition of $\mathrm{Na}_{2} \mathrm{~S}$, a required amount of $\mathrm{CaO}$ was introduced to the purified filtrate for tin precipitation as calcium stannate trihydrate $\left(\mathrm{CaSnO}_{3} \cdot 3 \mathrm{H}_{2} \mathrm{O}\right)$. Finally, the obtained $\mathrm{CaSnO}_{3} \cdot 3 \mathrm{H}_{2} \mathrm{O}$ powder was heated at $800{ }^{\circ} \mathrm{C}$ for obtaining the final $\mathrm{CaSnO}_{3}$ product.

\subsection{Analytical Techniques}

In this study, the chemical composition of samples from all the experiments was determined using inductively coupled plasma-optical emission spectrometry (ICP-OES) (IRIS Intrepid II XSP, Thermo Scientific, Waltham, MA, USA) following digestion with a mixture of concentrated $\mathrm{HCl}$ and $\mathrm{HNO}_{3}(3: 1, v / v)$ [34]. The phase composition of tin, antimony, and lead contained in the lead refining dross was determined following selective leaching and ICP-OES analysis. The crystalline phases were determined by X-ray diffraction (XRD) (TTR-III, Rigaku, Tokyo, Japan) in $2 \theta$ scale with a copper target 
(CuK $\alpha_{1}$ radiation, $\lambda=1.5406,50 \mathrm{Kv}$, and $100 \mathrm{~mA}$ ) at the scanning rate of $10 \mathrm{deg} / \mathrm{min}$ varying from 10 to $80 \mathrm{deg}$. The morphologies of the solid samples were investigated by scanning electron microscopy (SEM) (JSM-6490LV, JEOL, Tokyo, Japan) coupled with energy dispersive spectroscopy (EDS) (JSM-6490LV, JEOL, Tokyo, Japan). Additionally, polished sections of powder samples were prepared for SEM-EDS analysis following bonding, cutting, grinding, and polishing processes. The precursor obtained was analyzed using thermo-gravimetric and differential thermal analysis (TG-DTA) with a thermal analyzer (STA 8000, PerkinElmer, Waltham, MA, USA) in flowing $\mathrm{N}_{2}$ at a heating rate of $10^{\circ} \mathrm{C} / \mathrm{min}$ from 20 to $1300{ }^{\circ} \mathrm{C}[35,36]$.

\section{Results and Discussion}

\subsection{Sodium Roasting of Lead Refining Dross}

To selectively convert $\mathrm{SnO}_{2}$ contained in dross to $\mathrm{Na}_{2} \mathrm{SnO}_{3}$ and thus to obtain a relatively high alkaline leaching efficiency of tin, it is necessary to optimize the operating parameters of sodium roasting. The reaction describing tin roasting by sodium carbonate is given by Equation (2) [37].

$$
\mathrm{Na}_{2} \mathrm{Co}_{3}+\mathrm{SnO}_{2}=\mathrm{Na}_{2} \mathrm{SnO}_{3}+\mathrm{CO}_{2}(\mathrm{~g})
$$

In this study, the effect of $\mathrm{Na}_{2} \mathrm{CO}_{3}$ dosage, roasting temperature, and time on tin leaching efficiency were investigated by applying the following fixed leaching conditions: $\mathrm{NaOH}$ concentration $2 \mathrm{~mol} / \mathrm{L}$, temperature $85{ }^{\circ} \mathrm{C}, 120 \mathrm{~min}$ reaction time, and $20 \mathrm{~mL} / \mathrm{g}$ liquid/solid ratio. The results are shown in Figure 3. As shown in Figure 3a, with increasing $\mathrm{Na}_{2} \mathrm{CO}_{3}$ dosage from $0 \%$ to $60 \%$, the leaching efficiency of tin significantly increases from $5 \%$ to $94 \%$, implying that the $\mathrm{SnO}_{2}$ contained in dross was converted to $\mathrm{Na}_{2} \mathrm{SnO}_{3}$, which is soluble in mild alkaline or acidic solutions. After that, the value has no significant change with further increasing $\mathrm{Na}_{2} \mathrm{CO}_{3}$ dosage, indicating that $60 \%$ of $\mathrm{Na}_{2} \mathrm{CO}_{3}$ addition is sufficient for $\mathrm{SnO}_{2}$ conversion to $\mathrm{Na}_{2} \mathrm{SnO}_{3}$.
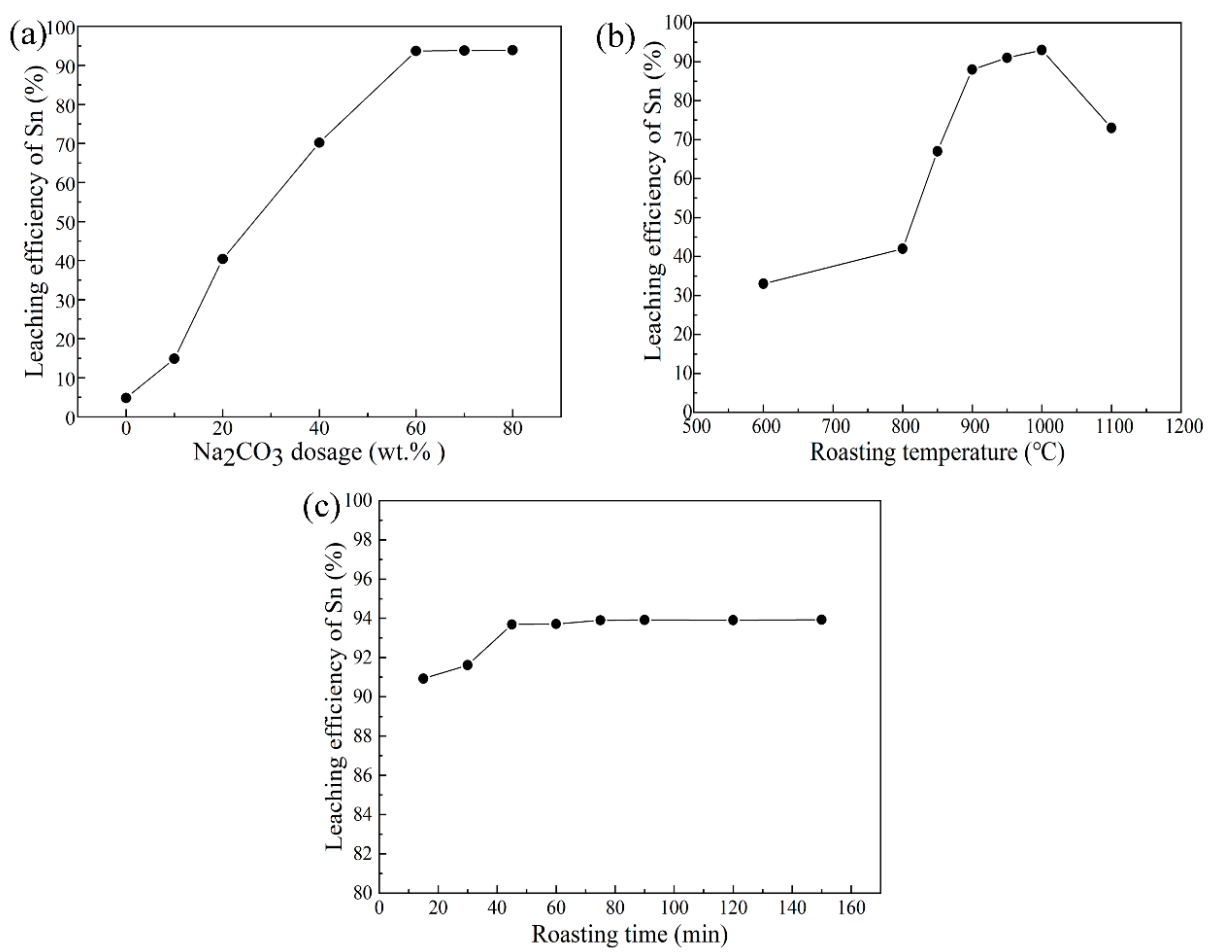

Figure 3. Effect of roasting parameters on leaching efficiency of tin: (a) $\mathrm{Na}_{2} \mathrm{CO}_{3}$ dosage $\left(1000{ }^{\circ} \mathrm{C}\right.$, $45 \mathrm{~min})$; (b) temperature $\left(60 \%\right.$ of $\left.\mathrm{Na}_{2} \mathrm{CO}_{3}, 45 \mathrm{~min}\right)$; (c) time $\left(60 \%\right.$ of $\left.\mathrm{Na}_{2} \mathrm{CO}_{3}, 1000{ }^{\circ} \mathrm{C}\right)$. 
Figure $3 \mathrm{~b}$ shows the effect of roasting temperature on tin leaching efficiency. It is seen that roasting temperature has a significant effect on the extraction of tin from lead refining dross. The leaching efficiency of tin moderately increases as the temperature increases from 600 to $800{ }^{\circ} \mathrm{C}$, above which the value increases markedly with the temperature increasing from 800 to $900{ }^{\circ} \mathrm{C}$. When the temperature is above $900{ }^{\circ} \mathrm{C}$, with the increase of temperature the leaching efficiency of tin increases slightly and reaches its maximum at $1000{ }^{\circ} \mathrm{C}$. After that, further increase of the temperature results in a decrease of tin recovery, which is probably attributed to the evaporation of molten sodium carbonate at high temperatures [38]. The optimum roasting temperature was considered to be $1000{ }^{\circ} \mathrm{C}$, and therefore further roasting experiments were performed at this temperature. Figure $3 \mathrm{c}$ shows the leaching efficiency of tin as a function of roasting time. It is obvious that roasting time also plays an important role in the extraction of tin from lead refining dross, but the effect of roasting time is less than that of $\mathrm{Na}_{2} \mathrm{CO}_{3}$ dosage or temperature in the ranges investigated. The leaching efficiency of tin increases observably as the time increases from 15 to $45 \mathrm{~min}$, after which the value has no significant variation, implying that the reaction of $\mathrm{SnO}_{2}$ and $\mathrm{Na}_{2} \mathrm{CO}_{3}$ almost completed within $45 \mathrm{~min}$. As a result, the optimum roasting time was determined as $45 \mathrm{~min}$.

To investigate the phase transformations during the roasting process, those roasted samples generated in the previous experiments were subjected to XRD analysis. The XRD patterns of the lead refining dross roasted at various conditions are presented in Figure 4. It was found that the main phase after roasting was $\mathrm{Na}_{2} \mathrm{SnO}_{3}$. It can be seen from Figure 4a that the sample roasted without $\mathrm{Na}_{2} \mathrm{CO}_{3}$ mainly contains $\mathrm{SnO}_{2}$ without any diffraction peaks of $\mathrm{Na}_{2} \mathrm{SnO}_{3}$. With the increase of $\mathrm{Na}_{2} \mathrm{CO}_{3}$ dosage, the peak intensity of $\mathrm{Na}_{2} \mathrm{SnO}_{3}$ gradually increases while that of $\mathrm{SnO}_{2}$ decreases. When the addition of $\mathrm{Na}_{2} \mathrm{CO}_{3}$ is $60 \%$ or above, the diffraction peaks of $\mathrm{SnO}_{2}$ disappear with a maximum peak intensity of $\mathrm{Na}_{2} \mathrm{SnO}_{3}$, indicating that the $\mathrm{Na}_{2} \mathrm{SnO}_{3}$ formation reaction is completed. This is in good agreement with the results in Figure $3 \mathrm{a}$. As shown in Figure $4 \mathrm{~b}$, it is obvious that there is no diffraction peak of $\mathrm{Na}_{2} \mathrm{SnO}_{3}$ observed from the XRD pattern at $600{ }^{\circ} \mathrm{C}$ The peaks of $\mathrm{Na}_{2} \mathrm{SnO}_{3}$ begin to appear at $800{ }^{\circ} \mathrm{C}$, which confirms the conclusion that the reaction of $\mathrm{SnO}_{2}$ and $\mathrm{Na}_{2} \mathrm{CO}_{3}$ mainly occurred at above $800{ }^{\circ} \mathrm{C}$. The peak intensity of $\mathrm{Na}_{2} \mathrm{SnO}_{3}$ firstly increases with the increase of roasting temperature while it decreases over $1000^{\circ} \mathrm{C}$, which is consistent with the conclusion obtained from Figure $3 \mathrm{~b}$. As seen from Figure $4 \mathrm{c}$, there are diffraction peaks of $\mathrm{SnO}_{2}$ in the sample roasted for $30 \mathrm{~min}$ demonstrating that the conversion to $\mathrm{Na}_{2} \mathrm{SnO}_{3}$ is incomplete. When the time is above $45 \mathrm{~min}$, no diffraction peak of $\mathrm{SnO}_{2}$ can be found, and the tin contained in the dross has been fully converted to $\mathrm{Na}_{2} \mathrm{SnO}_{3}$. It is thus indicated that a 45 min roasting time is sufficient for the transformation, which confirms the conclusions drawn from Figure 3c.

To investigate the morphological characterization of the dross roasted under the optimal conditions, the sample was analyzed by SEM-EDS. The results are presented in Figure 5. It is seen from Figure 5 that the roasted dross is porous and loose compared with the sample before roasting (Figure 1), which is attributed to the gas generated during roasting process. This is beneficial to the lixivium penetrating into the roasted dross particles and thus accelerates the dissolution of tin during the subsequent alkaline leaching process. According to EDS analysis combined with XRD (Figure 4), it is revealed that the tin contained in the roasted dross was mainly in the form of sodium stannate. Additionally, it is seen in Figure 5 that there is some iron, antimony, and lead in the roasted samples, which have not been detected by XRD due to their low content. 

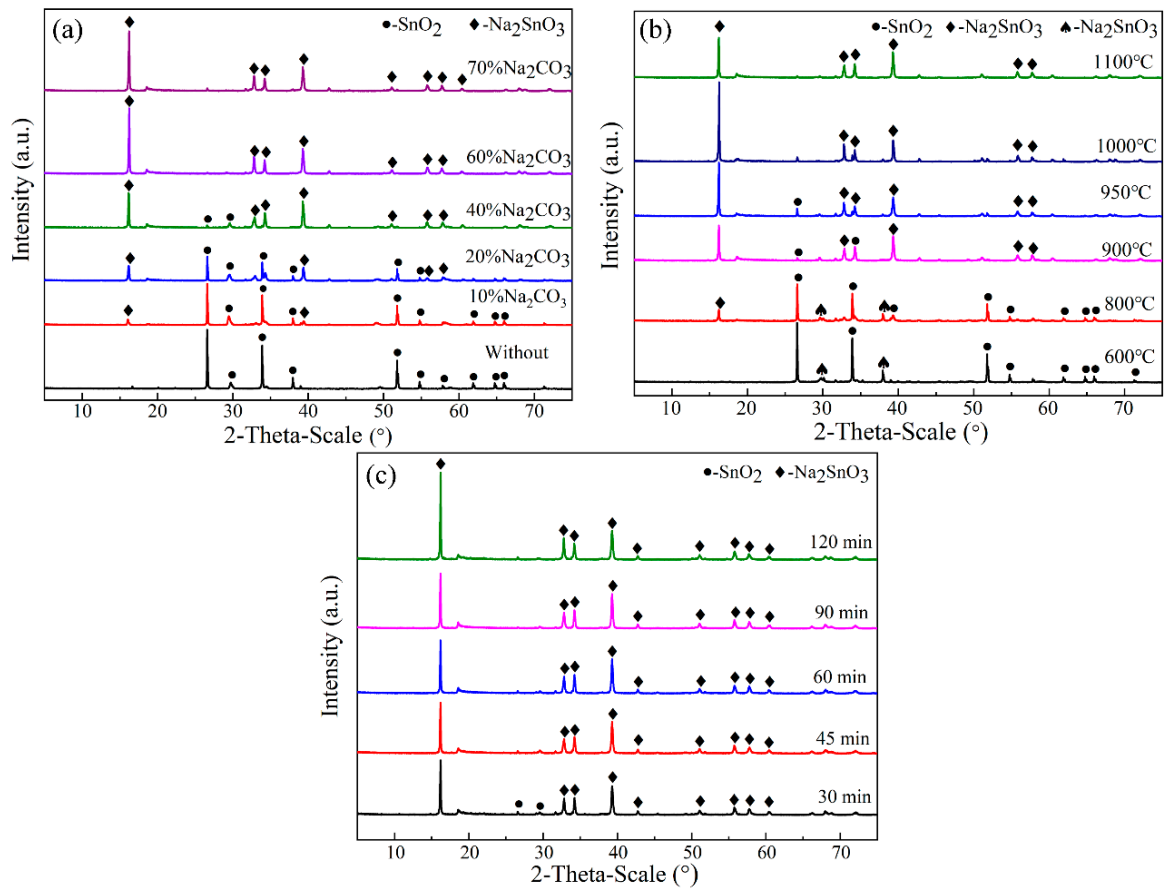

Figure 4. XRD patterns of the lead refining dross roasted at various conditions: (a) different $\mathrm{Na}_{2} \mathrm{CO}_{3}$; (b) roasting temperature; (c) roasting time.


Figure 5. SEM-EDS results of the dross roasted under the optimal conditions: $60 \%$ sodium carbonate dosage, temperature $1000{ }^{\circ} \mathrm{C}$, and time $45 \mathrm{~min}$.

\subsection{Alkaline Leaching of Tin}

In hydrometallurgy, E-pH diagrams of $\mathrm{Me}-\mathrm{H}_{2} \mathrm{O}$ systems are widely used to analyze the thermodynamic conditions of a leaching process [29]. The E-pH diagrams of $\mathrm{Sn}-\mathrm{H}_{2} \mathrm{O}$ at 25 and $100{ }^{\circ} \mathrm{C}$ were drawn by the thermodynamic calculation method [39]. Note that the concentrations of 
related metallic ions are fixed at $1 \mathrm{M}$, and both of the partial pressures of oxygen and hydrogen are at the standard atmospheric pressure of $101.325 \mathrm{KPa}$. The E-pH diagrams of $\mathrm{Sn}-\mathrm{H}_{2} \mathrm{O}$ system shown in Figure 6 indicate that the transformation of $\mathrm{Sn} \rightarrow \mathrm{Sn}(\mathrm{IV})$ occurs in the whole $\mathrm{pH}$ range investigated. $\mathrm{Sn}(\mathrm{IV})$ exists in the form of $\mathrm{SnO}_{3}^{2-}$ in the alkaline solution, and it tends to precipitate as $\mathrm{Sn}(\mathrm{OH})_{4}$ and further dissolve as $\mathrm{Sn}^{4+}$ with the decrease of the $\mathrm{pH}$ value $[40,41]$. Based on the above analysis, tin can be selectively extracted with an alkaline solution.

Based on the above thermodynamic analysis, the selective extraction of tin from the lead refining dross roasted under the optimized conditions $\left(60 \% \mathrm{Na}_{2} \mathrm{CO}_{3}\right.$ dosage at $1000{ }^{\circ} \mathrm{C}$ for $\left.45 \mathrm{~min}\right)$ was further studied. The effects of $\mathrm{NaOH}$ concentration, leaching temperature, time, and liquid/solid ratio on the leaching efficiency of tin were investigated in detail. The results are shown in Figure 7 . The possible chemical reaction during the leaching process was assumed as follows [42]:

$$
\mathrm{Na}_{2} \mathrm{SnO}_{3}+\mathrm{H}_{2} \mathrm{O}=\mathrm{Na}_{2}[\mathrm{Sn}(\mathrm{OH}) 6](\mathrm{aq})
$$
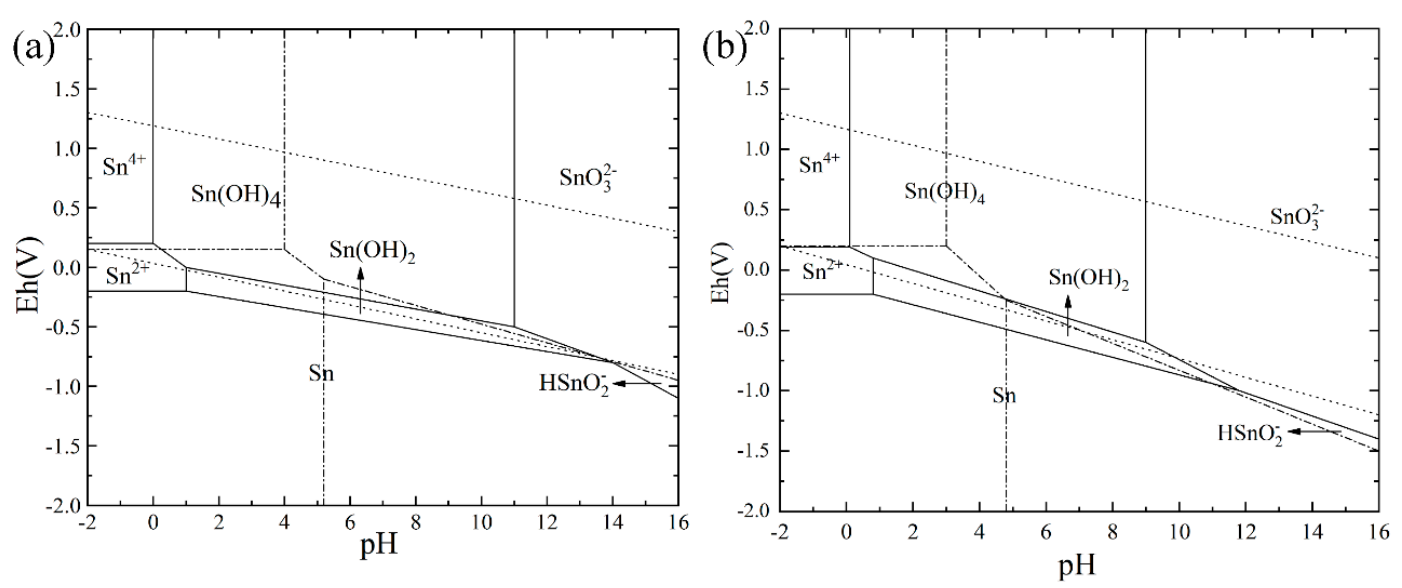

Figure 6. E-pH diagrams of $\mathrm{Sn}-\mathrm{H}_{2} \mathrm{O}$ systems at (a) $25^{\circ} \mathrm{C}$ and (b) $100{ }^{\circ} \mathrm{C}$.

(a)
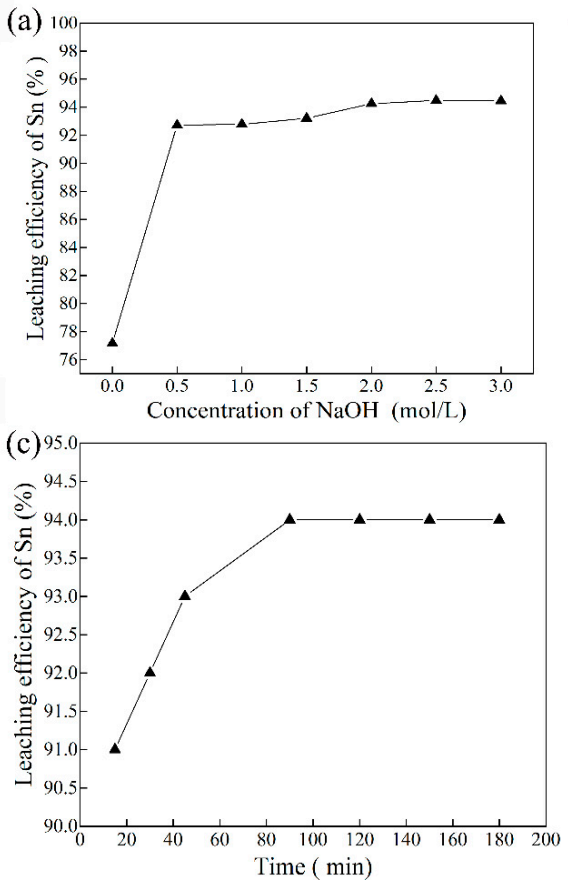

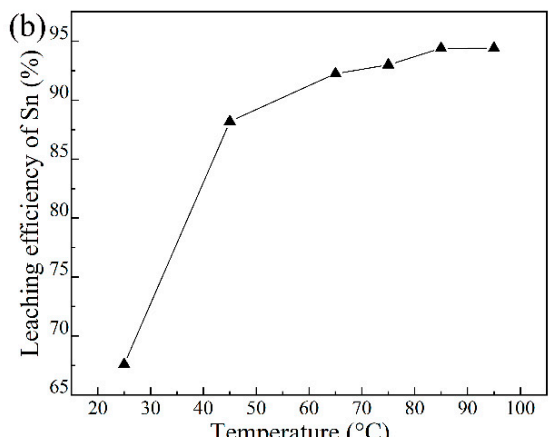

(d)



Figure 7. Effect of leaching conditions on leaching efficiency of tin: (a) $\mathrm{NaOH}$ concentration; (b) temperature; (c) time; (d) liquid/solid ratio. 
As shown in Figure 7a, the leaching efficiency of tin increases from $77 \%$ to $94 \%$ with the increase of $\mathrm{NaOH}$ concentration from 0 to $2 \mathrm{~mol} / \mathrm{L}$. Further increase of $\mathrm{NaOH}$ concentration has no significant effect on tin leaching, indicating that $2 \mathrm{~mol} / \mathrm{L}$ of $\mathrm{NaOH}$ concentration is sufficient for the leaching of tin. Figure $7 \mathrm{~b}$ reveals that leaching temperature has a positive effect on the leaching efficiency of tin. The value increases significantly when the temperature increases from 25 to $85^{\circ} \mathrm{C}$, which is attributed to the fact that the increase of leaching temperature results in the increase of the ion diffusion coefficient and decrease of the activation energy of the dissolution reaction [43]. Thereafter, it remains nearly constant. It is seen from Figure 7c that the leaching efficiency of tin could reach 90\% in 15 min, which demonstrates that the leaching rate is fast. This confirms the conclusion obtained from Figure 5. With the increase of leaching time, the leaching efficiency of tin gradually increases until it reaches its maximum value $(94 \%)$ at $90 \mathrm{~min}$. Further increasing the reaction time has no significant effect on leaching efficiency, indicating that the soluble tin contained in the roasted dross has been leached completely. It is seen in Figure $7 \mathrm{~d}$ that the liquid/solid ratio has an important effect on tin leaching efficiency which increases from about $86 \%$ to $94 \%$ by increasing the liquid/solid ratio from 4 to $8 \mathrm{~cm}^{3} / \mathrm{g}$, above which no significant variation is seen.

Based on the above discussion, the optimal conditions for the selective leaching of tin from the roasted lead refining dross were determined as: $\mathrm{NaOH}$ concentration $2 \mathrm{~mol} / \mathrm{L}$, leaching temperature $85^{\circ} \mathrm{C}$, leaching time $90 \mathrm{~min}$, and liquid/solid ratio equal to $8 \mathrm{~cm}^{3} / \mathrm{g}$. Under the conditions, more than $94 \%$ of tin and about $45 \% \mathrm{~Pb}$ were extracted from the dross.

\subsection{Precipitation and Characterization of Calcium Stannate}

The leachate obtained under the optimum conditions contained about $25.5 \mathrm{~g} / \mathrm{L} \mathrm{Sn}, 1.5 \mathrm{~g} / \mathrm{L} \mathrm{Pb}$, and $0.12 \mathrm{~g} / \mathrm{L} \mathrm{Sb}$. The $\mathrm{pH}$ value of the leachate was 12.8. To obtain a pure calcium stannate product, $\mathrm{Na}_{2} \mathrm{~S}$ was added into the filtrate obtained from the alkaline leaching process to remove lead ions, according to the following Equation (4) [39].

$$
\mathrm{HPbO}_{2}^{-}+\mathrm{H}_{2} \mathrm{O}+\mathrm{S}^{2-}=\mathrm{PbS} \downarrow+3 \mathrm{OH}^{-}
$$

Subsequently, after the purification process, precipitation of stannate ions from the filtrate at a $\mathrm{pH}$ value of 13.5 using $\mathrm{CaO}$ powder was performed to produce a calcium stannate precursor according to the following reaction:

$$
\mathrm{Na}_{2} \mathrm{SnO}_{3}+\mathrm{CaO}+4 \mathrm{H}_{2} \mathrm{O}=\mathrm{CaSnO}_{3} \cdot 3 \mathrm{H}_{2} \mathrm{O}+2 \mathrm{NaOH}
$$

The XRD patterns of the precursor shown in Figure 8 indicate that the sample was a well crystallized calcium stannate trihydrate $\left(\mathrm{CaSn}(\mathrm{OH})_{6}\right.$ or $\left.\mathrm{CaSnO}_{3} \cdot 3 \mathrm{H}_{2} \mathrm{O}\right)$. The precursor was analyzed by TG-DTA for investigating its thermal decomposition dehydration behavior. The results are also shown in Figure 8. The weight loss of $9.5 \%$ from room temperature to $318.5^{\circ} \mathrm{C}$ was mainly attributed to the evaporation of physically adsorbed water. The decomposition reaction of calcium stannate trihydrate (Equation (6)) started at about $318.5^{\circ} \mathrm{C}$, and finished at $816.1^{\circ} \mathrm{C}$, which is in good agreement with previous studies $[44,45]$. The reaction equation is as follows:

$$
\mathrm{CaSnO}_{3} \cdot 3 \mathrm{H}_{2} \mathrm{O}=\mathrm{CaSnO}_{3}+3 \mathrm{H}_{2} \mathrm{O}(\mathrm{g})
$$

The XRD pattern of the final product, which was produced after calcination of the precursor containing calcium stannate trihydrate at $800^{\circ} \mathrm{C}$, shown in Figure 9, indicates that its main phase is $\mathrm{CaSnO}_{3}$, whereas chemical analysis following digestion and ICP-OES analysis indicated that its purity was $95.75 \%$. The product was also subjected to SEM-EDS analysis, and the results are presented in Figure 10. The SEM images shown in Figure 10a-c revealed that almost all of the sample particles are smaller than $5 \mu \mathrm{m}$ with a compact structure, clear edges, and boundaries between different particles, 
demonstrating that the product had a good crystallinity. EDS analysis (Figure 10d) indicated that the product contained $\mathrm{O}, \mathrm{Sn}$, and $\mathrm{Ca}$, which confirmed the high purity of the sample.

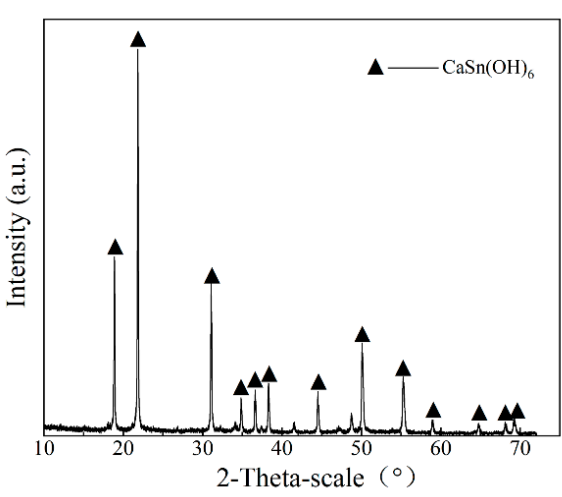

(a)

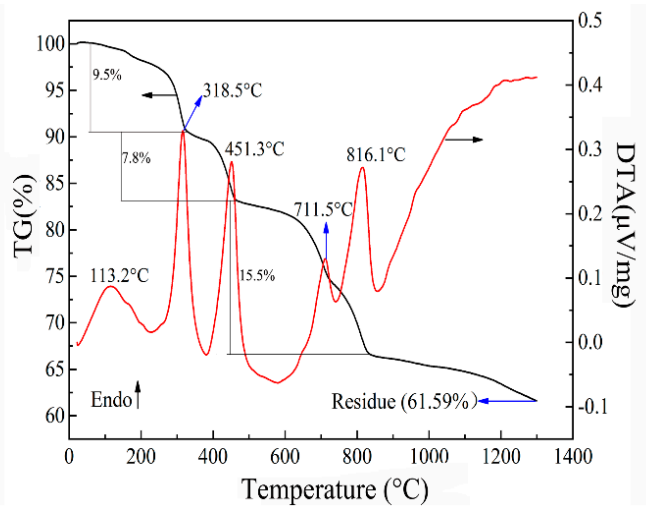

(b)

Figure 8. XRD pattern (a) and thermo-gravimetric and differential thermal analysis (TG-DTA) curves (b) of the precursor $\left(\mathrm{CaSnO}_{3} \cdot 3 \mathrm{H}_{2} \mathrm{O}\right)$.

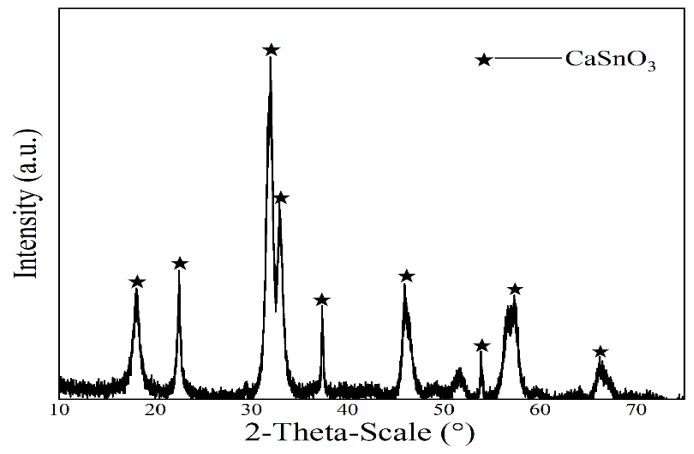

Figure 9. XRD pattern of the calcium stannate obtained.
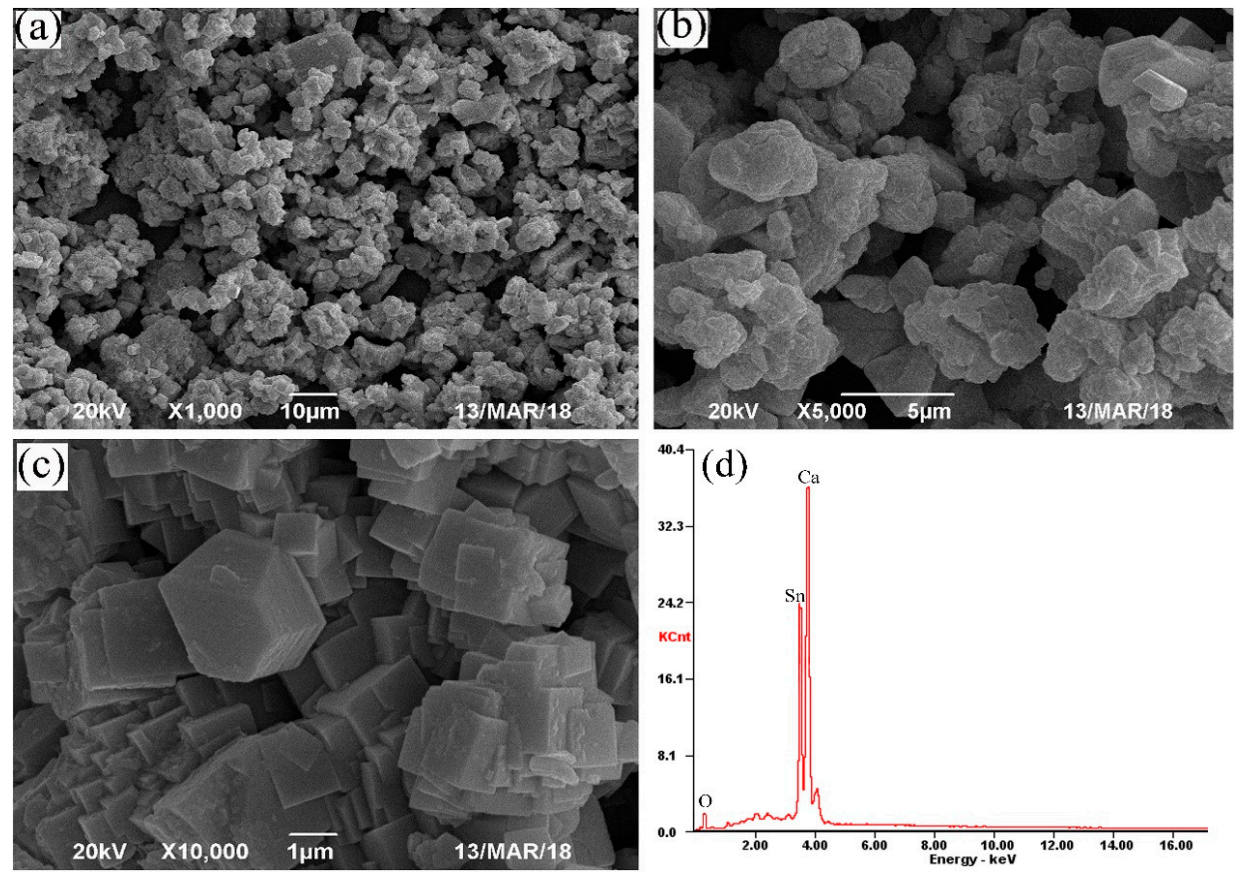

Figure 10. SEM-EDS results of the calcium stannate obtained: (a) 1000 times magnification; (b) 5000 times magnification; (c) 10,000 times magnification; (d) EDS spectrum. 


\section{Conclusions}

Calcium stannate was produced from lead refining dross by applying sodium carbonate roasting,

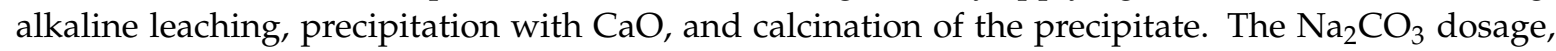
roasting temperature, roasting time, $\mathrm{NaOH}$ concentration, leaching temperature, leaching time, and liquid/solid ratio have different effects on the extraction of tin from lead refining dross. The optimal conditions resulting in higher tin recovery include roasting at $1000{ }^{\circ} \mathrm{C}$ for $45 \mathrm{~min}$ and $60 \% \mathrm{Na}_{2} \mathrm{CO}_{3}$ dosage, and leaching using $2 \mathrm{~mol} / \mathrm{L} \mathrm{NaOH}$ solution for $90 \mathrm{~min}$ at $85^{\circ} \mathrm{C}$, and an $8 \mathrm{~cm}^{3} / \mathrm{g}$ liquid/solid ratio. Under these conditions, more than $94 \% \mathrm{Sn}$ and about $45 \%$ Pb were extracted from the dross. The lead dissolved in the leachate was effectively removed by adding $\mathrm{Na}_{2} \mathrm{~S}$. Subsequently, more than $99 \%$ of tin was precipitated from the purified solution by a causticizing process and the precipitate was calcinated to produce a final $\mathrm{CaSnO}_{3}$ product with a purity of $95.75 \%$. SEM analysis indicated that the resulting product has a compact structure, clear edges, and clear boundaries between different particles. This study should contribute to fundamental knowledge that can be used to guide the preparation of calcium stannate from lead refining dross, which is missing in the literature at present.

Author Contributions: J.H. developed the idea and revised the manuscript; D.W. performed the experiments and wrote the manuscript; W.L., F.J. and W.Q. provided theoretical direction; all authors discussed the results.

Funding: This research was funded by the National Natural Science Foundation of China (grant number 51804342, 51874356, and 51604302), the Natural Science Foundation of Hunan Province (grant number 2019JJ50805), the Innovation Driven Plan of Central South University (grant number 2015CX005), Key Laboratory of Hunan Province for Clean and Efficient Utilization of Strategic Calcium-Containing Mineral Resources (grant number 2018TP1002), and the Scientific Research Starting Foundation of Central South University (grant number 218041). The APC was funded by the Scientific Research Starting Foundation of Central South University (grant number 218041).

Acknowledgments: We would like to thank the editor and reviewers for the processing and comments on this paper.

Conflicts of Interest: The authors declare no conflict of interest.

\section{References}

1. Kong, X.; Yang, B.; Xiong, H.; Liu, D.; Xu, B. Removal of impurities from crude lead with high impurities by vacuum distillation and its analysis. Vacuum 2014, 105, 17-20. [CrossRef]

2. Hong, J.; Yu, Z.; Shi, W.; Hong, J.; Qi, C.; Ye, L. Life cycle environmental and economic assessment of lead refining in China. Int. J. Life Cycle Assess. 2016, 22, 909-918. [CrossRef]

3. Hayre, C.M.; Blackman, S.; Carlton, K.; Eyden, A. Attitudes and perceptions of radiographers applying lead $(\mathrm{Pb})$ protection in general radiography: An ethnographic study. Radiography 2018, 24, e13-e18. [CrossRef] [PubMed]

4. Li, J.; Ge, S.; Wang, J.; Du, H.; Song, K.; Fei, Z.; Shao, Q.; Guo, Z. Water-based rust converter and its polymer composites for surface anticorrosion. Colloids Surf. A 2018, 537, 334-342. [CrossRef]

5. Tan, J.; Cao, Z.-F.; Wang, S.; Zhong, H. Selective recovery of lead from galena-sphalerite by electro-oxidation. Hydrometallurgy 2019, 185, 218-225. [CrossRef]

6. Bai, L.; Qiao, Q.; Li, Y.; Wan, S.; Xie, M.; Chai, F. Statistical entropy analysis of substance flows in a lead smelting process. Resour. Conserv. Rec. 2015, 94, 118-128. [CrossRef]

7. Bai, L.; Qiao, Q.; Li, Y.; Xie, M.; Wan, S.; Zhong, Q. Substance flow analysis of production process: A case study of a lead smelting process. J. Clean. Prod. 2015, 104, 502-512. [CrossRef]

8. Lee, H.Y. Preparation of basic lead carbonate from lead dust by hydrometallurgical processes. Hydrometallurgy 2009, 96, 103-107. [CrossRef]

9. Onisei, S.; Pontikes, Y.; Van Gerven, T.; Angelopoulos, G.N.; Velea, T.; Predica, V.; Moldovan, P. Synthesis of inorganic polymers using fly ash and primary lead slag. J. Hazard. Mater. 2012, 205-206, 101-110. [CrossRef]

10. Ellis, T.W.; Mirza, A.H. The refining of secondary lead for use in advanced lead-acid batteries. J. Power Sources 2010, 195, 4525-4529. [CrossRef]

11. Fu, Z.; Kong, J.H.; Gajjala, S.R.; Koc, R. Sintering, mechanical, and oxidation properties of TiC-Ni-Mo cermets obtained from ultra-fine TiC powders. J. Alloys Compd. 2018, 751, 316-323. [CrossRef] 
12. Zhang, Y.; Deng, J.; Jiang, W.; Mei, Q.; Liu, D. Application of vacuum distillation in refining crude lead. Vacuum 2018, 148, 140-148. [CrossRef]

13. Binz, F.; Friedrich, B. Recovery of Antimony Trioxide Flame Retardants from Lead Refining Residues by Slag Conditioning and Fuming. Chem. Ing. Tech. 2015, 87, 1569-1579. [CrossRef]

14. Lewis, A.E.; Beautement, C. Prioritising objectives for waste reprocessing: A case study in secondary lead refining. Waste Manag. 2002, 22, 677-685. [CrossRef]

15. Ojebuoboh, F.; Wang, S.; Maccagni, M. Refining primary lead by granulation-leaching-electrowinning. JOM 2003, 55, 19-23. [CrossRef]

16. Bin, Z.; Chen, J.; Shafi, M.; Guo, J.; Wang, Y.; Wu, J.; Ye, Z.; He, L.; Liu, D. Effect of lead (Pb) on antioxidation system and accumulation ability of Moso bamboo (Phyllostachys pubescens). Ecotoxicol. Environ. Saf. 2017, 138, 71-77. [CrossRef]

17. Cai, L.-M.; Xu, Z.-C.; Qi, J.-Y.; Feng, Z.-Z.; Xiang, T.-S. Assessment of exposure to heavy metals and health risks among residents near Tonglushan mine in Hubei, China. Chemosphere 2015, 127, 127-135. [CrossRef]

18. De Andrade Lima, L.R.P.; Bernardez, L.A. Characterization of the lead smelter slag in Santo Amaro, Bahia, Brazil. J. Hazard. Mater. 2011, 189, 692-699. [CrossRef]

19. Girault, F.; Perrier, F.; Poitou, C.; Isambert, A.; Théveniaut, H.; Laperche, V.; Clozel-Leloup, B.; Douay, F. Effective radium concentration in topsoils contaminated by lead and zinc smelters. Sci. Total Environ. 2016, 566-567, 865-876. [CrossRef]

20. Gump, B.B.; Dykas, M.J.; MacKenzie, J.A.; Dumas, A.K.; Hruska, B.; Ewart, C.K.; Parsons, P.J.; Palmer, C.D.; Bendinskas, K. Background lead and mercury exposures: Psychological and behavioral problems in children. Environ. Res. 2017, 158, 576-582. [CrossRef]

21. Thomas, V.G.; McGill, I.R. Dissolution of copper, tin, and iron from sintered tungsten-bronze spheres in a simulated avian gizzard, and an assessment of their potential toxicity to birds. Sci. Total Environ. 2008, 394, 283-289. [CrossRef]

22. Yan, W.; Mahmood, Q.; Peng, D.; Fu, W.; Chen, T.; Wang, Y.; Li, S.; Chen, J.; Liu, D. The spatial distribution pattern of heavy metals and risk assessment of moso bamboo forest soil around lead-zinc mine in Southeastern China. Soil Til. Res. 2015, 153, 120-130. [CrossRef]

23. Su, Z.; Zhang, Y.; Liu, B.; Lu, M.; Li, G.; Jiang, T. Extraction and Separation of Tin from Tin-Bearing Secondary Resources: A Review. JOM 2017, 69, 2364-2372. [CrossRef]

24. International Tin Association. Available online: https://www.internationaltin.org/reports/2016-report-onglobal-tin-resourcesreserves/ (accessed on 26 August 2018).

25. Kekesi, T.; Torok, T.I.; Kabelik, G. Extraction of tin from scrap by chemical and electrochemical methods in alkaline media. Hydrometallurgy 2000, 55, 213-222. [CrossRef]

26. Kim, S.-K.; Lee, J.-C.; Yoo, K. Leaching of tin from waste Pb-free solder in hydrochloric acid solution with stannic chloride. Hydrometallurgy 2016, 165, 143-147. [CrossRef]

27. Yoo, K.; Lee, J.-C.; Lee, K.-S.; Kim, S.-K.; Pandey, B.D. Recovery of Sn, Ag and Cu from Waste Pb-Free Solder Using Nitric Acid Leaching. Mater. Trans. 2012, 53, 2175-2180. [CrossRef]

28. Yang, B.; Kong, L.-X.; Xu, B.-Q.; Liu, D.-C.; Dai, Y.-N. Recycling of metals from waste Sn-based alloys by vacuum separation. Trans. Nonferr. Metal. Soc. 2015, 25, 1315-1324. [CrossRef]

29. Han, J.; Liang, C.; Liu, W.; Qin, W.; Jiao, F.; Li, W. Pretreatment of tin anode slime using alkaline pressure oxidative leaching. Sep. Purif. Technol. 2017, 174, 389-395. [CrossRef]

30. Kim, E.; Horckmans, L.; Spooren, J.; Vrancken, K.C.; Quaghebeur, M.; Broos, K. Selective leaching of Pb, Cu, $\mathrm{Ni}$ and $\mathrm{Zn}$ from secondary lead smelting residues. Hydrometallurgy 2017, 169, 372-381. [CrossRef]

31. Guo, X.; Liu, J.; Qin, H.; Liu, Y.; Tian, Q.; Li, D. Recovery of metal values from waste printed circuit boards using an alkali fusion-leaching-separation process. Hydrometallurgy 2015, 156, 199-205. [CrossRef]

32. Li, D.; Guo, X.; Xu, Z.; Tian, Q.; Feng, Q. Leaching behavior of metals from copper anode slime using an alkali fusion-leaching process. Hydrometallurgy 2015, 157, 9-12. [CrossRef]

33. Zhang, R.-L.; Qiu, K.-Q. Research on extracting tin and preparation of sodium stannate from slag containing tin. Min. Metall. 2008, 1, 34-37. (In Chinese)

34. Han, J.; Liu, W.; Wang, D.; Jiao, F.; Zhang, T.; Qin, W. Selective Sulfidation of Lead Smelter Slag with Pyrite and Flotation Behavior of Synthetic ZnS. Metall. Mater. Trans. B 2016, 47, 2400-2410. [CrossRef]

35. Liu, W.; Xu, J.; Han, J.; Jiao, F.; Qin, W.; Li, Z. Kinetic and Mechanism Studies on Pyrolysis of Printed Circuit Boards in the Absence and Presence of Copper. ACS Sustain. Chem. Eng. 2019, 7, 1879-1889. [CrossRef] 
36. Liu, W.; Zhong, X.; Han, J.; Qin, W.; Liu, T.; Zhao, C.; Chang, Z. Kinetic Study and Pyrolysis Behaviors of Spent $\mathrm{LiFePO}_{4}$ Batteries. ACS Sustain. Chem. Eng. 2019, 7, 1289-1299. [CrossRef]

37. Liu, B.; Zhang, Y.; Su, Z.; Li, G.; Jiang, T. Function mechanism of $\mathrm{CO}-\mathrm{CO}_{2}$ atmosphere on the formation of $\mathrm{Na}_{2} \mathrm{SnO}_{3}$ from $\mathrm{SnO}_{2}$ and $\mathrm{Na}_{2} \mathrm{CO}_{3}$ during the roasting process. Powder Technol. 2016, 301, 102-109. [CrossRef]

38. Zhang, Y.; Su, Z.; Liu, B.; You, Z.; Yang, G.; Li, G.; Jiang, T. Sodium stannate preparation from stannic oxide by a novel soda roasting-leaching process. Hydrometallurgy 2014, 146, 82-88. [CrossRef]

39. Liu, W.; Li, W.; Han, J.; Wu, D.; Li, Z.; Gu, K.; Qin, W. Preparation of calcium stannate from lead refining slag by alkaline leaching-purification-causticization process. Sep. Purif. Technol. 2019, 212, 119-125. [CrossRef]

40. Buckle, R.; Roy, S. The recovery of copper and tin from waste tin stripping solution: Part I. Thermodynamic analysis. Sep. Purif. Technol. 2008, 62, 86-96. [CrossRef]

41. Yang, C.; Li, J.; Tan, Q.; Liu, L.; Dong, Q. Green Process of Metal Recycling: Coprocessing Waste Printed Circuit Boards and Spent Tin Stripping Solution. ACS Sustain. Chem. Eng. 2017, 5, 3524-3534. [CrossRef]

42. Choi, Y.-I.; Salman, S.; Kuroda, K.; Okido, M. Synergistic corrosion protection for AZ31 Mg alloy by anodizing and stannate post-sealing treatments. Electrochim. Acta 2013, 97, 313-319. [CrossRef]

43. Han, J.; Liu, W.; Qin, W.; Yang, K.; Wang, D.; Luo, H. Innovative methodology for comprehensive utilization of high iron bearing zinc calcine. Sep. Purif. Technol. 2015, 154, 263-270. [CrossRef]

44. Pfaff, G. Chemical synthesis of calcium stannates from peroxo precursors. Mater. Sci. Eng. B 1995, 33, 156-161. [CrossRef]

45. He, Z.-Q.; Li, X.-H.; Liu, E.-H.; Hou, Z.-H.; Deng, L.F.; Hu, C.-Y. Preparation of calcium stannate by modified wet chemical method. J. Cent. South Univ. Technol. 2003, 10, 195-197. [CrossRef]

(C) 2019 by the authors. Licensee MDPI, Basel, Switzerland. This article is an open access article distributed under the terms and conditions of the Creative Commons Attribution (CC BY) license (http://creativecommons.org/licenses/by/4.0/). 